\title{
Callus induction and betacyanin quantification by HPLC/MS-MS in Alternanthera brasiliana (L.) Kuntze ${ }^{1}$
}

\author{
Andressa Reis ${ }^{2}$, Alítcia Moraes Kleinowski², Fátima Rosane Schuquel Klein², \\ Renata Trevizan Telles de Souza ${ }^{2}$, Luciano do Amarante ${ }^{3}$ and Eugenia Jacira Bolacel Braga ${ }^{3,4}$
}

Received: 5.9.2016; aceito: 9.12.2016

\begin{abstract}
Callus induction and betacyanin quantification by HPLC/MS-MS in Alternanthera brasiliana (L.) Kuntze). The objective of this study was to establish a protocol for callus induction and betacyanin production in plants of Alternanthera brasiliana. Explants of $A$. brasiliana and five combinations of cytokinin and auxin were used for callus induction. Calli were transferred to a Betacyanin Induction Medium (MIB), composed of MS, with $0.5 \mathrm{mg} \mathrm{L}^{-1}$ of thidiazuron (TDZ) and $1 \mathrm{mg} \mathrm{L}^{-1}$ of naphthaleneacetic acid (NAA), and kept in the light for 45 days. The aspect and intensity of pigments were assessed and total betacyanins were quantified in high performance liquid chromatography (HPLC). The combination of internodal segments and a medium containing equilibrium concentrations of auxins and cytokinins was the most efficient metod to induce calli and increased production of betacyanins. The presence of amaranthine in calli of $A$. brasiliana justifies its medical use and the consequent need for future studies for the large-scale production of this molecule.
\end{abstract}

Keywords: in vitro growth, medicinal plants, phyto-regulators, pigments

RESUMO - (Indução de calo e quantificação de betacianinas por CLAE/MS-MS em Alternanthera brasiliana (L.) Kuntze). O objetivo deste estudo foi estabelecer um protocolo para indução de calos e produção de betacianinas em plantas de Alternanthera brasiliana. Para indução da calogênese foram utilizados explantes de $A$. brasiliana e cinco combinações de citocinina e auxina. Posteriormente os calos foram transferidos para Meio de Indução de Betacianinas (MIB), formado por meio MS, com $0,5 \mathrm{mg} \mathrm{L}^{-1}$ de tidiazuron (TDZ) e $1 \mathrm{mg} \mathrm{L}^{-1}$ de ácido naftalenoacético (ANA), onde permaneceram na luz por 45 dias. Avaliou-se oaspecto e a intensidade de pigmentos e quantificação de betacianinas totais em Cromatografia Líquida de Alta Eficiência (CLAE). Os segmentos internodais combinados com o meio que contém equilíbrio na concentração de auxinas e citocininas foi mais eficiente para obtenção de calogênese e maior produção de betacianinas. A presença de amarantina, em calos de $A$. brasiliana, justifica seu uso medicinal e contribui para futuros estudos para produção em larga escala desta molécula.

Palavras-chave: cultivo in vitro, fitorreguladores, plantas medicinais, pigmentos

\section{Introduction}

Several species of the genus Alternanthera (Amaranthaceae family) have been used in folk medicine for the treatment of diseases, as pharmacological studies have confirmed their important biological properties, justifying their popular use (Facundo et al. 2012). Alternanthera brasiliana (L.) Kuntze has been used frequently in the treatment of various diseases, such as infectious and pain processes, besides having important antioxidant and antibacterial activity (Barua et al. 2013, Trapp et al. 2015).
These reported pharmacological activities are associated with secondary metabolites that this plant produces and the presence of flavonoids, such as kaempferol and quercetin (Kannan et al. 2014), in addition to terpenes, steroids, phenolic compounds and pigments of the betalain class (Hundiwale et al. 2012). The latter are nitrogenous pigments soluble in water which present great chemotaxonomic importance, because they are exclusively from plants of the Caryophyllales order (Khan \& Giridhar 2015). The interest in these pigments has grown since their antioxidant activity was characterized and

1. Parte da Dissertação de Mestrado do primeiro Autor

2. Universidade Federal de Pelotas, Instituto de Biologia, Departamento de Botânica, Laboratório de Cultura de Tecidos de Plantas, 96010-610 Pelotas, RS, Brasil

3. Universidade Federal de Pelotas, Departamento de Ciências Químicas, Laboratório de Bioquímica Vegetal, Centro de Farmacêutica e Alimentos 96010-610 Pelotas, RS, Brasil

4. Correspondence author: jacirabraga@hotmail.com 
subsequently they have been widely employed as additives for food, drugs and cosmetics due to their natural coloring properties and absence of toxicity (Volp et al. 2008).

The culture of calli and plant cells is currently an important strategy for bioprospecting natural products and has been used as an alternative in the production of a wide range of secondary metabolites that are difficult to obtain chemically, including some natural dyes such as betacyanins (Shim et al. 2010).

In addition, the modification of the concentration and type of culture medium allows a significant increase in the production of biomass and accumulation of secondary metabolites (Karuppusamy 2009), demonstrating that in vitro production of bioactive compounds for the purposes of herbal medicines, pharmaceutical products, food additives and cosmetics should be encouraged due to their scientific, economic and ecological importance (Biswas et al. 2013).

Thus, in the effort to take a first step toward developing procedures related to betacyanin synthesis in plants of the genus Alternanthera, this study aimed to establish an efficient protocol for callus induction in plants of Alternanthera brasiliana and quantify the production of betacyanins by high performance liquid chromatography (HPLC) in the calli formed.

\section{Material and methods}

Callus induction - A. brasiliana plants were kept in MS medium (Murashige \& Skoog 1962) containing $30 \mathrm{~g} \mathrm{~L}^{-1}$ sucrose, $8 \mathrm{~g} \mathrm{~L}^{-1}$ agar and $100 \mathrm{mg} \mathrm{L}^{-1}$ inositol in a growth chamber with $22 \mu \mathrm{mol} \mathrm{m} \mathrm{m}^{-2} \mathrm{~s}^{-1}$ photon flux density, $16 \mathrm{~h}$ photoperiod and a temperature of $25 \pm 2{ }^{\circ} \mathrm{C}$ for 30 days. The plants were collected in the municipalities of Rio Grande, state of RS (2006) and identified by the agronomist Elen Nunes Garcia. A voucher specimen was deposited in the Herbarium of the Botany Department of the Federal University of Pelotas, in RS, registration number 24535.

Leaf segments measuring $0.5 \times 1 \mathrm{~cm}$ and internodal segments measuring approximately $1 \mathrm{~cm}$ long were used as the initial explants for callus induction. The leaf segments were lacerated diagonally three times and placed in Petri dishes $(90 \times 15 \mathrm{~mm})$, containing basic MS supplemented with $30 \mathrm{~g} \mathrm{~L}^{-1}$ of sucrose, $2 \mathrm{~g} \mathrm{~L}^{-1}$ phytagel, $100 \mathrm{mg} \mathrm{L}^{-1}$ inositol, $0.5 \mathrm{mg} \mathrm{L}^{-1}$ adenine, $3 \mathrm{mg} \mathrm{L}^{-1}$ ascorbic acid (AA) and different combinations of growth regulators. Five different combinations of growth regulators were added to the basic medium described above: Medium 1:1 $\mathrm{mg} \mathrm{L}^{-1}$ of kinetin (KIN) and $1 \mathrm{mg} \mathrm{L}^{-1}$ of 2,4-dichlorophenoxyacetic acid (2,4-D); Medium 2: $2.5 \mathrm{mg} \mathrm{L}^{-1}$ of naphthaleneacetic acid (NAA) and $1 \mathrm{mg}$ $\mathrm{L}^{-1}$ of 5-benzylaminopurine (BAP); Medium 3: 0.75 $\mathrm{mg} \mathrm{L}^{-1}$ of indole-3-acetic acid (IAA) and $1 \mathrm{mg} \mathrm{L}^{-1}$ of 2,4-D; Medium 4: $0.5 \mathrm{mg} \mathrm{L}^{-1}$ of BAP and $1 \mathrm{mg} \mathrm{L}^{-1}$ of 2.4-D and Medium 5: $1 \mathrm{mg} \mathrm{L}^{-1}$ of BAP and $0.5 \mathrm{mg}$ $\mathrm{L}^{-1}$ of 2.4-D. The explants remained in the dark (D) for 22 days and after that period were transferred to the light (L), where they were kept for eight days on a $16 \mathrm{~h}$ photoperiod at a temperature of $25^{\circ} \mathrm{C} \pm 2$.

Production of betacyanin - After establishment of the experiment, the calli from all callus induction media (CIM) were transferred to Betacyanin induction media (BIM) (Zhao et al. 2010), consisting of MS, containing $0.3 \%$ phytagel, $30 \mathrm{~g} \mathrm{~L}^{-1}$ sucrose, $100 \mathrm{mg} \mathrm{L}^{-1}$ inositol, $0.5 \mathrm{mg} \mathrm{L}^{-1}$ adenine, $3 \mathrm{mg} \mathrm{L}^{-1}$ ascorbic acid and supplemented with $0.5 \mathrm{mg} \mathrm{L}^{-1}$ of thidiazuron (TDZ) and $1 \mathrm{mg} \mathrm{L}^{-1}$ naphthaleneacetic acid (NAA). Calli remained in this medium for 45 days under white light on a $16 \mathrm{~h}$ photoperiod at a temperature of $25^{\circ} \mathrm{C} \pm 2$. The BIM was replaced with fresh medium every 15 days.

Qualitative assessments were also carried out at the end of the growth period for appearance and intensity of pigments (magenta color) in the calli, (Reis 2013). For the aspect of color (percentage of pigmentation in calli) the following scores were used : 0 (absence of magenta pigmentation), 1 (random spots of magenta pigmentation), 2 (50\% magenta pigmentation), 3 (100\% magenta pigmentation) and for intensity of magenta color: 0 (no pigment), 1 (low intensity), 2 (moderate intensity), 3 (high intensity). The test was carried out by four evaluators for both parameters.

Total betacyanins were extracted in $10 \mathrm{mM}$ sodium acetate buffer, $\mathrm{pH} 5.0$, plus $10 \mathrm{mM}$ ascorbic acid (AA) and homogenized in a Polytron (Kinematica AG, Switzerland), in two 5-second pulses, at medium speed. The extract was filtered in gauze and centrifuged at $120,000 \times \mathrm{g}$ for $40 \mathrm{~min}$. The supernatant was filtered in a YM-10 Centriplus membrane (Millipore) to remove the protein and filtrate for the pigment analysis. The process was carried out at $4{ }^{\circ} \mathrm{C}$. High performance liquid chromatography (HPLC) in reverse phase was performed according to the method of Gandia-Herrero et al. (2007), in a Shimadzu LC10A unit, coupled to a photodiode array detector (PAD), model SPD-M10A (Shimadzu, Kyoto, Japan). $25 \mu \mathrm{L}$ of extract were used in a Kromasil packed column, model $100 \mathrm{C}-18(250 \times 4.6 \mathrm{~mm})$, with $5 \mu \mathrm{m}$ particles (Tecnokroma, Barcelona, Spain). The solvent gradients had mobile phases composed of milli-Q water acidified with $0.05 \%$ trifluoroacetic acid (solvent 
A) and acetonitrile acidified with $0.05 \%$ trifluoroacetic acid (solvent B), with a flow rate of $1 \mathrm{~mL} \mathrm{~min}^{-1}$.

An 1100 VL Agilent LC/MSD was used for the analysis in HPLC coupled to a Mass Spectrometer (MS/MS) (Agilent Technologies, Palo Alto, CA). The elution conditions were the same as those of the previous analysis. The interface between the HPLC and MS/MS consisted of an electrospray ionization source, at $3.5 \mathrm{kV}$, with a nebulizer gas flow rate $\left(\mathrm{N}_{2}\right)$ of $0.8 \mathrm{~mL} \mathrm{~min}^{-1}$ pressure of drying gas $\left(\mathrm{N}_{2}\right)$ at $35 \mathrm{psi}$, and vaporization temperature of $350^{\circ} \mathrm{C}$. The mass spectra were acquired in the positive ionization mode, with full scan in the range of $60-1000 \mathrm{~m} / \mathrm{z}$. For detection, the electron multiplier voltage was $1350 \mathrm{~V}$.

The experimental design used for the evaluation of callus induction was completely randomized in a $5 \times 2$ factorial scheme (five media and two types of explants), containing four replicates per treatment, using a Petri dish containing five explants. The evaluations were carried out 15 and 30 days after inoculation of explants in the media and analyzed separately. For the betacyanin evaluation, only callus induction media of internode explants were compared. The data were subjected to analysis of variance and comparison of averages by Tukey test at $5 \%$ probability of error, with the aid of the statistical software WinStat (Machado \& Conceição 2002).

\section{Results and Discussion}

Callus formation was observed in internodal explants at 15 days of growth in all growth media, while growth of calli in leaf explants was obtained only in medium $1(100 \%)$ and medium $2(70 \%)$, showing the internode to be the organ presenting the quickest callus induction in the species investigated (table 1).

Callus formation involves cell differentiation, division and growth that are regulated by phytoregulators, such as cytokinins and auxins (Gao et al. 2011). For the species investigated, only the combination of these two phyto-regulators was found to be effective in callogenesis induction (medium 1 and 2) in leaf explants, while the use of 2,4-D was sufficient for callus formation in the case of internodal explants, which presented no significant differences in the five media tested. Regardless of the evaluation period, all the mediawere considered effective inducers of calli in that organ.

In studies in Solanum melongena, Ray et al. (2011) reported a minimum period of 10 days necessary for callus induction in internode explants, which is in line with the period of 15 days necessary for callus induction in A. brasiliana. On the other hand, at this time some of the media presented $100 \%$ formed calli, different from findings of the above mentioned authors, who found maximum values of $48.7 \%$ for the species investigated.

These results allow us to consider internodal explants as a potential biosynthetically active tissue for betacyanin induction, since theses pigments are produced in the aerial part of $A$. brasiliana plants. Similar results were reported by Biswas et al. (2013) in Amaranthus tricolor.

Culture of tissues has been considered an alternative for producing a wide range of secondary metabolites that are difficult to obtain chemically, including natural stains. Establishment of callus cultures has been reported as a possible means specifically for synthesizing magenta calli, whose main pigmentation are betacyanins (Trejo-Tapia et al . 2008). Thus, following the period of pigmentation induction, the calli were qualitatively evaluated for pigmentation and medium 2 presented no magenta in the calli, while medium 1 presented some explants with rose pigments and media 3, 4 and 5 presented greater homogeneity of colors, with the formation of rose pigments (figure 1).

The values for color aspect and intensity in leaf and internode explants are presented in table 2. In terms of aspect, as can be seen, both organs presented good pigmentation, with means varying from 0.75 to 2 for internodes and 0.5 to 2 for leaves. The media that presented the greatest production of pigment were 5 and 3, for internodes and leaves, respectively, and the color in both explants in medium 4 did not differ statistically.

The leaf explants in medium containing only auxins (medium 3 ) presented the greatest pigmentation at the end of the growth period. In the internodal explants, a concentration of cytokinin twice that of auxin produced greater pigmentation in the calli.

Based on these results, auxins such as 2,4-D, when associated to another auxin, such as IAA, may stimulate the biosynthesis of betacyanin in leaves, but to stimulate pigment synthesis in internodes of A. brasiliana it is suggested that this auxin be used in combination with the cytokinin BAP.

In a study conducted with Amaranthus tricolor, calli with higher concentrations of betacyanin were grown in medium containing NAA $\left(0.25 \mathrm{mg} \mathrm{L}^{-1}\right)$ and BAP $\left(2 \mathrm{mg} \mathrm{L}^{-1}\right)$, while in study of calli of Beta vulgaris, growth in MS medium plus $\operatorname{KIN}\left(0.1 \mathrm{mg} \mathrm{L}^{-1}\right)$ and 2,4-D (1 $\left.\mathrm{mg} \mathrm{L}^{-1}\right)$ of hypocotyl explants produced calli with heterogeneous pigmentation (several 
Table 1- Percentage of callus induction in explants of Alternanthera brasiliana at different periods of growth in MS media containing different growth regulators.

\begin{tabular}{lcccc}
\hline \multirow{2}{*}{ Media (mg L-1) } & \multicolumn{2}{c}{15 days } & \multicolumn{2}{c}{30 days } \\
\cline { 2 - 5 } & Internodes & Leaves & Internodes & Leaves \\
\hline Medium 1 (1.0 KIN + 1.0 2,4-D) & $100 \mathrm{Aa}$ & $20 \mathrm{Ba}$ & $100 \mathrm{Aa}$ & $100 \mathrm{Aa}^{*}$ \\
Medium 2 (2.5 NAA + 1.0 BA) & $85 \mathrm{Aa}$ & $0 \mathrm{Bb}$ & $100 \mathrm{Aa}$ & $70 \mathrm{Bb}$ \\
Medium 3 (0.75 IAA+ 1.0 2,4-D) & $95 \mathrm{Aa}$ & $0 \mathrm{Bb}$ & $95 \mathrm{Aa}$ & $0 \mathrm{Bc}$ \\
Medium 4 (0.5 BA + 1.0 2,4-D) & $100 \mathrm{Aa}$ & $5 \mathrm{Bab}$ & $100 \mathrm{Aa}$ & $5 \mathrm{Bc}$ \\
Medium 5 (1.0 BA + 0.5 2,4-D) & $100 \mathrm{Aa}$ & $0 \mathrm{Bb}$ & $100 \mathrm{Aa}$ & $0 \mathrm{Bc}$ \\
\hline
\end{tabular}

*Means followed by the same letters, lower case in the row and uppercase in the column, do not differ statistically by the Tukey test at a level of $5 \%$.

Table 2. Effect of growth regulators on the appearance and intensity of color in calli from internodes and leaves of Alternanthera brasiliana at the end of the growth period.

\begin{tabular}{lcccc}
\hline \multirow{2}{*}{ Media (mg L-1) } & \multicolumn{2}{c}{ Coloring aspect* } & \multicolumn{2}{c}{ Staining intensity ** } \\
& Internodes & Leaves & Internodes & Leaves \\
\hline Medium 1 (1.0 KIN + 1.0 2,4-D) & $0.75 \mathrm{Aab}$ & $0.75 \mathrm{Aa}$ & $1.25 \mathrm{Aa}$ & $1.25 \mathrm{Aa}^{* * *}$ \\
Medium 2 (2.5 NAA + 1.0 BA) & $0.5 \mathrm{Ab}$ & $0.75 \mathrm{Aa}$ & $1 \mathrm{Aa}$ & $1.25 \mathrm{Aa}$ \\
Medium 3 (0.75 IAA+ 1.0 2,4-D) & $1.0 \mathrm{Bab}$ & $2 \mathrm{Aa}$ & $1 \mathrm{Aa}$ & $1.75 \mathrm{Aa}$ \\
Medium 4 (0.5 BA+1.0 2,4-D) & $1.25 \mathrm{Aab}$ & $1.75 \mathrm{Aa}$ & $1.5 \mathrm{Aa}$ & $2.5 \mathrm{Aa}$ \\
Medium 5 (1.0 BA + 0.5 2,4-D) & $2 \mathrm{Aa}$ & $1 \mathrm{Ba}$ & $3 \mathrm{Aa}$ & $2 \mathrm{Aa}$ \\
\hline
\end{tabular}

* The values for aspect of color are the mean of four evaluators using the criteria: 0 (absence of magenta), 1 (random spots of magenta), 2 (50\% magenta pigmentation), 3 (100\% magenta pigmentation).

** The values for pigment intensity are the mean of four evaluators who using the criteria: 0 (non-existent), 1 (low), 2 (moderate), 3 (high).

****Means followed by the same letters, lowercase in the row and uppercase in the column do not differ statistically by the Tukey test at a level of $5 \%$.

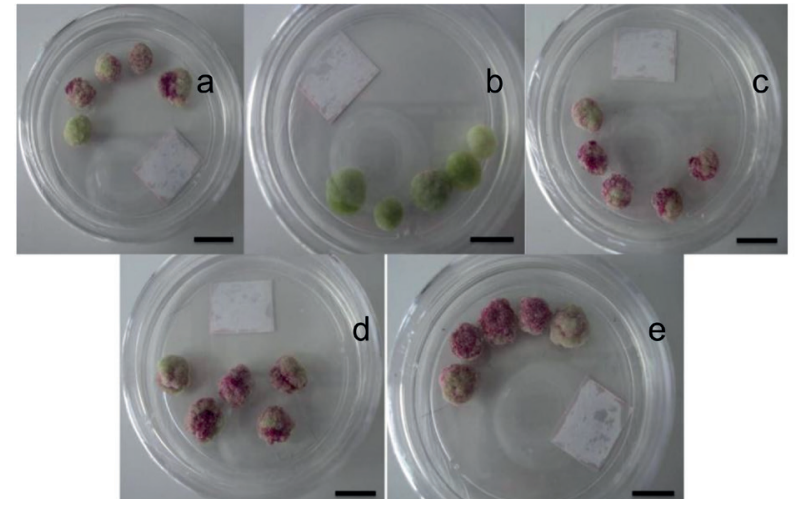

Figure 1. Pigmentation in calli of Alternanthera brasiliana using internodes as explants indifferent media, after 30 days of culture in BIM. (A) Medium 1: $1 \mathrm{mg} \mathrm{L}^{-1} \mathrm{KIN}$ and $1 \mathrm{mg} \mathrm{L}^{-1} 2,4-\mathrm{D}$; (B) Medium 2: $2.5 \mathrm{mg} \mathrm{L}^{-1} \mathrm{NAA}$ and $1 \mathrm{mg} \mathrm{L}^{-1} \mathrm{BA}$;(C) Medium 3: $0.75 \mathrm{mg} \mathrm{L}^{-1}$ IAA and $1 \mathrm{mg} \mathrm{L}^{-1}$ 2,4-D; (D) Medium 4: $0.5 \mathrm{mg} \mathrm{L}^{-1} \mathrm{BA}^{-1}$ and $1 \mathrm{mg}$ $\mathrm{L}^{-1}$ 2,4-D and (E) Medium 5: $1 \mathrm{mg} \mathrm{L}^{-1} \mathrm{BA}$ and $0.5 \mathrm{mg} \mathrm{L}^{-1}$ 2,4-D. The bar indicates $1 \mathrm{~cm}$. pigments) and leaf explants produced calli with red coloring (Trejo-Tapia et al. 2008).

As for color intensity, the five media were able to produce moderate to high color intensity in calli from both leaf and internodal explants, showing no statistical differences (table 2). However, the media that showed prominence were $\operatorname{BAP}\left(0.5 \mathrm{mg} \mathrm{L}^{-1}\right)+2,4-\mathrm{D}\left(1 \mathrm{mg} \mathrm{L}^{-1}\right)$ for calli of leaf explants and 2,4-D $\left(0.5 \mathrm{mg} \mathrm{L}^{-1}\right)+\mathrm{BAP}(1$ $\left.\mathrm{mg} \mathrm{L}^{-1}\right)$ for calli from internodal explants, demonstrating that a combination of auxins and cytokinins is beneficial and necessary for the increased intensity of pigments, as shown by Macedo et al. (1999). In studies with Chenopodium rubrum and B. vulgaris low concentrations of 2,4-D induced the production of betacyanin (Biswas et al. 2013) and, according to Kugler et al. (2007), the color results from the betacyanin/betaxanthin ratio and batochromic change characteristic of acylated and nonacylated betacyanins. 
One serious obstacle in the development of systems for large-scale production based on plant cells has been instability in the accumulation of metabolites. Several reports have shown the gradual loss of capacity and production standards or high variation in levels of secondary metabolites (Trejo-Tapia et al. 2008).

To determine the type and quantity of pigment produced in internodal calli, analyses using high performance liquid chromatography (HPLC) and an analytic curve, respectively, were performed and the results are presented in figure 2. A greater increase in betacyanins was found in extracts of calli from medium 3, with $262 \mu \mathrm{mol}$ of amaranthine $\mathrm{g}^{-1}$ of dry mass (DM), followed by medium 1, with $174 \mu \mathrm{mol}$ of amaranthine $\mathrm{g}^{-1} \mathrm{DM}$.

Tissues, organs or cells with varying intensities of determination can acquire new capacities through the action of chemical signals (growth regulators) that selectively activate certain genes (epigenesis) and the final response is morphogenetic expression, which can sometimes lead to organogenesis of the tissue. According to the results obtained in the quantification of betacyanins in HPLC-MS, the presence of a considerable content of amaranthine was confirmed, possibly resulting from interaction between different growth regulators in the callus induction media (CIM) in the first phase of development and the regulators present in the betacyanin induction media (BIM), leading to expression of this inherent potential of cells.

Figure 3 shows the HPLC chromatogram of the aqueous extract of calli grown in medium 3 , monitored at $536 \mathrm{~nm}$. In this medium, four main peaks were found with the standard (amaranthine), which are molecules of amaranthine (betanidin-5-O- $\beta$-glucuronosyl glycoside) with a retention time (rt) of $15.77 \mathrm{~min}$, isoamarathine (isobetanidin-5-O- $\beta$-glucuronosyl glycoside) with rt of $16.87 \mathrm{~min}$, bethanidine with rt of $18.28 \mathrm{~min}$ and isobethanidine with tr of $19.65 \mathrm{~min}$.

The presence of variable concentrations of amaranthine and isoamarathine can be explained by the fact that auxins increase levels of polysomy and ploidy in different organs, according to studies with $B$. vulgaris, showing that this can affect the type of betalains expressed and their production in the presence of multiple copies of genes involved in the biosynthesis of these pigments (Weber et al. 2010). Studies in Phytolacca americana demonstrated that addition of cytokinins to the media decreased the accumulation of betalains, showing that the BAP reduces the incorporation of tyrosine in betacyanins in more than $50 \%$ of the cases (Hirano et al. 1992). The BIM was composed of another cytokinin, thidiazuron, which has

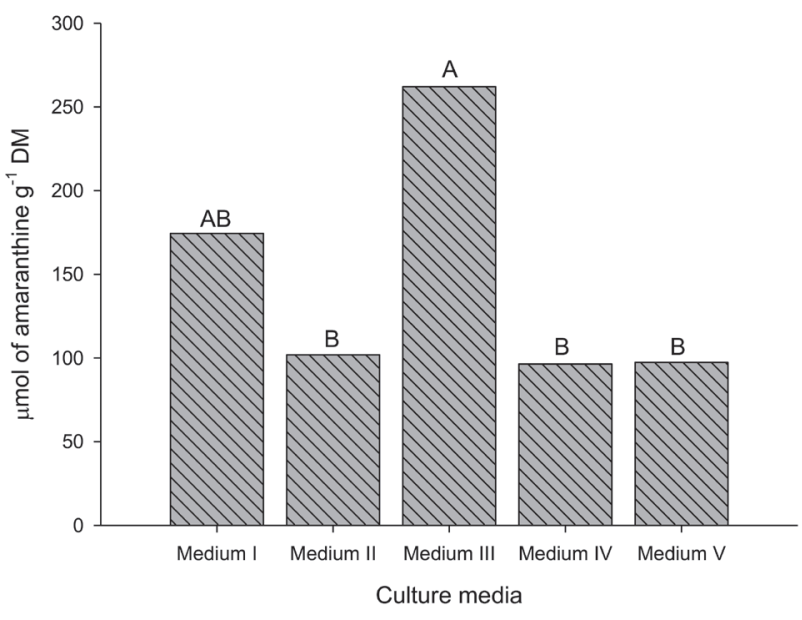

Figure 2. Amaranthine concentration in calli from internodes of Alternanthera brasiliana, grown in different growth media, at the end of 60 days. *Means followed by the same letters do not differ statistically, according to the Tukey test $(\mathrm{p}<0.05)$. Abbreviations: DM, dry mass.

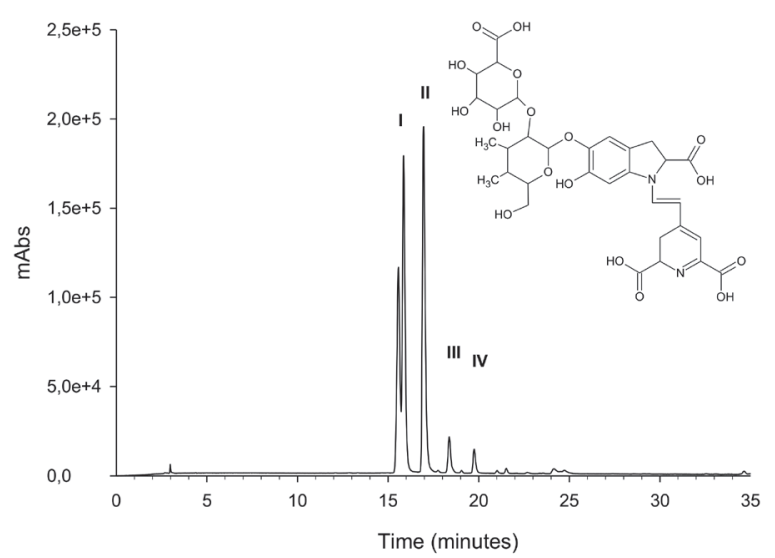

Figure 3. Chromatogram of the aqueous extract of Alternathera brasiliana calli grown on culture medium $3\left(0.75 \mathrm{mg} \mathrm{L}^{-1}\right.$ of IAA and $\left.1 \mathrm{mg} \mathrm{L}^{-1} 2,4-\mathrm{D}\right)$ in the wavelenght at $536 \mathrm{~nm}$. Alongside, the molecule of Amaranthine, confirmed by mass spectrometry. I - Amaranthine (betanidin-5-O- $\beta$-glucuronosylglucoside); II isoamaranthine (isobetanidin-5-O- $\beta$-glucuronosylglucoside); III - betanidine IV - isobetanidine.

been used to induce physiological responses such as regulation of cell division, growth and differentiation of tissues and organs (Bhuiyan \& Adachi 2003) and, more recently, TDZ has emerged as a highly effective bioregulator in tissue cultures of diverse species, ranging from trees to herbaceous species.

\section{Conclusion}

This study enabled the establishment of a protocol for callus induction for the species A. brasiliana, based on the balanced use of auxins and cytokinins. 
This pioneer study identified, by HPLC, the presence of betacyanin and amaranthine in calli of $A$. brasiliana and showed that MS media supplemented with auxins are the most effective for greater production of this molecule. The presence of this nontoxic pigment in this species justifies its use in folk medicine and shows the need for future studies for its large-scale production.

\section{Acknowledgements}

To the institutions and people who have made this work possible, mainly, the Coordenação de Aperfeiçoamento de Pessoal de Nível Superior (CAPES), for financial support and the $\mathrm{CNPq}$ (Conselho Nacional de Desenvolvimento Científico e Tecnológico) for their financial support and researcher fellowships EJBB; to the Universidad de Murcia, and researcher Dr. Fernando Gandía-Herrero, for the receptiveness towards our group and providing the HPLC and other equipment for phytochemical analyses.

\section{Literature cited}

Barua, C.C., Begum, S.A., Pathak, D.C., Bora, R.S. 2013. Wound healing activity of Alternanthera brasiliana Kuntze and its anti oxidant profiles in experimentally induced diabetic rats. Journal of Applied Pharmaceutical Science 10: 161-165.

Biswas, M., Das, S.S., Dey, S. 2013. Establishment of a stable Amaranthus tricolor callus line for production of food colorant.Food Science and Biotechnology 22: 1-18.

Bhuiyan, N.H \& Adachi, T. 2003. Stimulation of betacyaninsyntesis through exogenous methyl jasmonate and other elicitors in suspension-cultured cells of Portulaca. Journal Plant Physiology 160: 1117-1124.

Facundo, V.A., Azevedo, M.S., Rodrigues, R.V., Nascimento, L.F.D., Militão, J.S., da Silva, G.V., Braz-Filho, R. 2012. Chemical constituents from three medicinal plants: Piper renitens, Siparuna guianensis and Alternanthera brasiliana. Revista Brasileira de Farmacognosia 22: 1134-1139.

Gandia-Herrero, F., Escribano, J., Garcia-Carmona, F. 2007. Characterization of the activity of tyrosinase on betanidin. Journal of Agricultural and Food Chemistry 55: 1546-1551.

Gao, J., Li, J., Luo, C., Yin, L., Li, S., Yang, G., He, G. 2011. Callus induction and plant regeneration in Alternanthera philoxeroides. Molecular biology reports 38:1413-1417.

Kannan, M., Chandran, R.P., Manju, S. 2014 . Preliminary phytochemical and antibacterial studies on leaf extracts of Alternanthera brasiliana (L.) Kuntze. International Journal Pharmacy and Pharmaceutical Sciences 6: 626-628.

Karuppusamy, S. 2009. A review on trends in production of secondary metabolites from higher plants by in vitro tissue, organ and cell cultures. Journal Medicinal Plants Research 3:1222-1239.
Khan, M.I \& Giridhar, P. 2015. Plant betalains: chemistry and biochemistry. Phytochemistry 117: 267-295.

Kugler, F., Stintzing, F.C., Carle, R. 2007. Characterisation of betalain patterns of differently coloured inflorescences from Gomphrena globosa L. and Bougainvillea sp. by HPLC-DAD-ESI-MS.Analytical and Bioanalytical Chemistry 387:637-648.

Hirano, H., Sakuta, M., Komamine, A. 1992. Inhibition by cytokinin of the accumulation of betacyanin in suspension cultures of Phytolacca americana. Zeitschrift für Naturforschung 47:705-710.

Hundiwale, J.C., Patil, A.V., Kulkarni, M.V., Patil, D.A., Mali, R.G. 2012. A current update on phytopharmacology of the genus Alternanthera. Journal of Pharmacy Research 5: 1924-1929.

Machado,A \& Conceição, A.R. 2002. Programa Estatístico WinStat - Sistema de Análise Estatístico para Windows. Versão 2.0. Pelotas: UFPEL.

Macedo, A.F., Barbosa, N.C., Esquibel, M.A., Souza, M.D., Cechinel-Filho, V. 1999. Pharmacological and phytochemical studies of callus culture extracts from Alternanthera brasiliana. Die Pharmazie 54: 776-777.

Ray, B. P., Hassan, L., Sarker, S.K. 2011. In vitro cultivation and regeneration of Solanum melongena (L.) using stem root and leaf explants. Nepal Journal of Biotechnology 1:49-54.

Reis, A. 2013. Síntese de betalaínas induzida pela luz em espécies do gênero Alternanthera. MD Thesis. Universidade Federal de Pelotas, Pelotas, Rio Grande do Sul, Brasil.

Shim, K.M., Hahn, E.J., Jeon, W.K., Paek, K. 2010. Accumulation of cell biomass anthraquinones, phenolics, and flavonoids as affected by auxin, cytokinin, and medium salt strength in cell suspension culture of Morinda citrifolia. Korean Journal of Horticultural Science \& Technology 28: 288-294.

Trapp, M.A., Kai, M., Mithöfer, A., Rodrigues-Filho, E. 2015. Antibiotic oxylipins from Alternanthera brasiliana and its endophytic bacteria.Phytochemistry 110: 72-82.

Trejo-Tapia, G., Balcazar-Aguilar, J. B., MartínezBonfil, B., Salcedo-Morales, G., Jaramillo-Flores, M., Arenas-Ocampo, M. L., Jiménez-Aparicio, A. 2008. Effect of screening and subculture on the production of betaxanthins in Beta vulgaris L. var.'Dark Detroit'callus culture. Innovative Food Science \& Emerging Technologies 9: 32-36.

Volp, A.C.P., Renhe, I.R.T., Stringueta, P.C. 2008. Pigmentos naturais bioativos. Alimentos e Nutrição Araraquara 20: 157-166.

Weber, B., Wenke, T., Frömmel, U., Schmidt, T., Heitkam, T. 2010. The Ty1-copia families SALIRE and Cotzilla populating the Beta vulgaris genome show remarkable differences in abundance, chromosomal distribution, and age. Chromosome research 18: 247-263.

Zhao, S.Z., Sun, H.Z., Chen, M., Wang, B.S. 2010. Light-regulated betacyanin accumulation in euhalophyte Suaeda salsa calli. Plant Cell Tissue Organ and Culture 102: 99-107. 